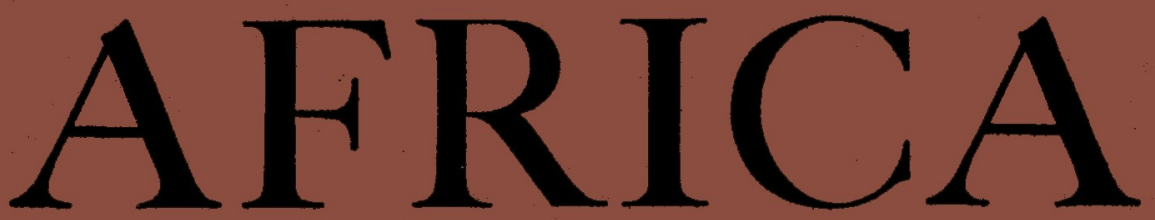

JOURNAL OF THE INTERNATIONAL INSTITUTE OF AFRICAN LANGUAGES AND CULTURES

JOURNAL DE L'INSTITUT INTERNATIONAL DES LANGUES ET CIVILISATIONS AFRICAINES

ZEITSCHRIFT DES INTERNATIONALEN INSTITUTS FÜR AFRIKANISCHE SPRACHEN UND KULTUREN

\title{
Editor
}

\section{DIEDRICH WESTERMANN}

\author{
Assistant Editor \\ D. G. BRACKET'T
}

Price

Six Shillings Net

OXFORD UNIVERSITY PRESS LONDON : HUMPHREY MILFORD 


\section{CONTENTS OF THIS NUMBER}

THE KULŨ IN NORTHERN NIGERIA. C. K. Meek

LES CAS DE POSSESSION ET L'EXORCISME CHEZ LES VANDAU. H. Ph. Junod

, 270

DIE BEDEUTUNG DES RINDES BEI DEN NUER. P. P. Crazzolara " 300 A RE-STATEMENT OF INDIRECT RULE. Margery Perham "32I METHODS OF STUDY OF CULTURE CONTACT. Monica Hunter " 335 LAMBA LITERATURE. C. M. Doke

PRIZES FOR BOOKS IN AFRICAN LANGUAGES. AWARDS IN FOURTH COMPETITION

" 374

NOTES AND NEWS

, 376

EXECUTIVE COUNCIL MEETING; THE STUDY OF CULTURE CONTACT; EDUCATION AND CULTURE CONTACTS; A NEW ORTHOGRAPHY FOR KIXUYU; ORTHOGRAPHIC REFORM IN SOUTHERN RHODESIA (Father Bertram H. Barnes, C.R.); 'LES LANGUES COMMUNES AU CONGO BELGE'; NOTE ON AN INVBSTIGATION OF THE BATCIGA (May Mandelbaum Edel); 'TOGO-CAMEROUN', MAGAZINE TRIMESTRIEL PUBLIÉ PAR L'AGENCE ECONOMIQUUB DES territotres africatnis sous mandat (M. le Professeur H. Labouret); vernacular. PERIODICAIS, NO. I4, 'KATOLIKA'.

REVIEWS OF BOOKS

the AFRICAN TO-DAY, by Diedrich Westermann (Hilda Matheson); unR population AFriCaINE, LES DYERMa : LA LANGUE SONGHAY, DIALECTE DYERMa, by Calonel Ardant du Picq (Henti Labouret); les Bayansi du Bas-KwILU, by $R$. de Beaurorps, S.J. (N. de Cleenc); AN OUTLINE OF DAHOMEAN RELIGious BELIEF, by $M$. $J$. Herskovits and F. S. Hershovits (D. Westermann); IL CAMMELLO; I REPARTI CAMMELLATT, by Massimo Adolfo Vitale (Max Hilzheimer); MISSION DAKAR-DJIBOUTI I93 I-1933 (J. Maes); GRAMmatica della lingua scilluk, by Padre B. Kohnen: OUtLines of a NUER Grammar, by Father J. P. Crazzolara (A. N. Tucker); BRITISH History FOR OVERSEAS STUDENTs, by W. E. Ward (M. M. Green).

NOTES ON CONTRIBUTORS

RUNDSCHAU UBER VEROFFENTLICHUNGEN IM GEBIETE AFRIKANISCHER SPRACHEN UND KULTUREN 